Reprod. Nutr. Dévelop., 1985, 25 (1 B), 169-173.

\title{
Lipogenesis as related to endocrine control of adipose cellularity in the rat
}

\author{
Christine LEVACHER, Carole SZTALRYD, L. PICON
}

Laboratoire de Physiologie du Développement (L.A. CNRS 307),

Université Paris 7, 2, place Jussieu, 75251 Paris Cedex 05, France.

Summary. The incorporation rate of ${ }^{3} \mathrm{H}$ from ${ }^{3} \mathrm{H}_{2} \mathrm{O}$ in the total lipids of rat retroperitoneal adipose tissue (RPAT) according to age was followed in slightly hyperthyroid rats, in type-2 diabetic rats and in control rats. Until 12 weeks of age, the RPAT of the hyperthyroid animals exhibited hyperplasia and an increase in lipogenesis per $\mathrm{g}$ of wet weight or per whole fat pad. Fat cell number and lipogenesis per $\mathrm{g}$ of wet weight or per whole fat pad were reduced in adult diabetic rats. The concomitant changes in fat cell number and lipid synthesis in the RPAT of the two groups of treated rats have been discussed.

\section{Introduction.}

The endocrine factors involved in the formation and maturation of new fat cells are not well known. We have recently shown in rats (1) that a moderate hyperthyroidal state, induced from birth, causes transitory hyperplasia of the retroperitoneal adipose tissue (RPAT) and epididymal adipose tissue while reducing fat cell size (Levacher et al., 1984) and (2) that type-2 diabetes produces long-lasting hypoplasia of the RPAT without a reduction in cell size (Goursot et al., 1981). The aim of this study was to determine if metabolic events induced by insulin or thyroxine had any features in common in respect to fat cell recruitment. In RPAT we examined de novo lipogenesis, one of the two pathways implicated in lipid accumulation in fat cells.

\section{Material and methods.}

Three groups of treated male Sherman rats were used. Within one day of birth, group 1 received streptozotocin $(100 \mu \mathrm{g} / \mathrm{g})$ in citrate buffer $(\mathrm{pH} \mathrm{4.5)}$ through the saphenous vein. On day 4 after birth, only animals with glycosuria were kept. The spontaneous development of neonatal diabetes led to a type-2 diabetic state in the adults (Portha, Picon and Rosselin, 1979). From birth, group 2 received a daily subcutaneous injection of thyroxine (DL $T_{4}: 0.3 \mu \mathrm{g} / \mathrm{g}$ ); group 3 constituted the control. 
The rats were studied at 3, 6, 12 and 18 weeks of age under Imalgene $(10 \mathrm{mg} / 100 \mathrm{~g})$ anaesthesia. Adipose tissue lipogenesis was estimated from the incorporation of ${ }^{3} \mathrm{H}$ from the ${ }^{3} \mathrm{H}_{2} \mathrm{O}$ in the total lipids (Fain et al., 1965) after intraperitoneal injection of $3 \mathrm{mCi}$ of ${ }^{3} \mathrm{H}_{2} \mathrm{O}$ at 2 p.m. Aortic puncture was performed $10 \mathrm{~min}$ later (Gandemer, Pascal and Durand, 1982). The RPAT was dissected and treated for lipid extraction (Folch, Lee and Sloane-Standey, 1957).

Lipogenesis was expressed in $\mu \mathrm{mol}$ of ${ }^{3} \mathrm{H}$ incorporated into lipids per $10 \mathrm{~min}$ per $\mathrm{g}$ of wet weight or per whole tissue. Usually we performed one determination per rat. However, the adipose tissues of 2 to 4 young animals were pooled.

\section{Results.}

In the adipose tissue of control rats, lipid synthesis per $\mathrm{g}$ of wet weight increased after weaning and then decreased after the age of 6 weeks. Expressed per whole fat pad, lipid synthesis increased throughout the growth phase (fig. 1).

In hyperthyroid rats, lipogenesis per $\mathrm{g}$ of wet weight (fig. 1) was significantly enhanced at 3 and 6 weeks of age and decreased thereafter, reaching the control values at 12 weeks. Although non-significant, lipogenesis per whole tissue changed in the same way (figs. 1,2).

Compared to controls the diabetic rats exhibited a non-significant but constant decrement in lipogenesis per $g$ of wet weight (fig. 1). Lipogenesis per whole fat pad (figs. 1, 2) decreased in 3,6 and 12-week old diabetic rats. This decrement was statistically significant at 12 weeks.

Compared to the controls, variations in lipogenesis per fat pad could not be related to changes in fat cell volume (fig. 2) or to changes in adipose tissue mass (not shown but very close to changes in fat cell volume) in either group of treated rats. However, fat cell number and lipogenesis in diabetic and hyperthyroid rats were altered concomitantly (fig. 2).

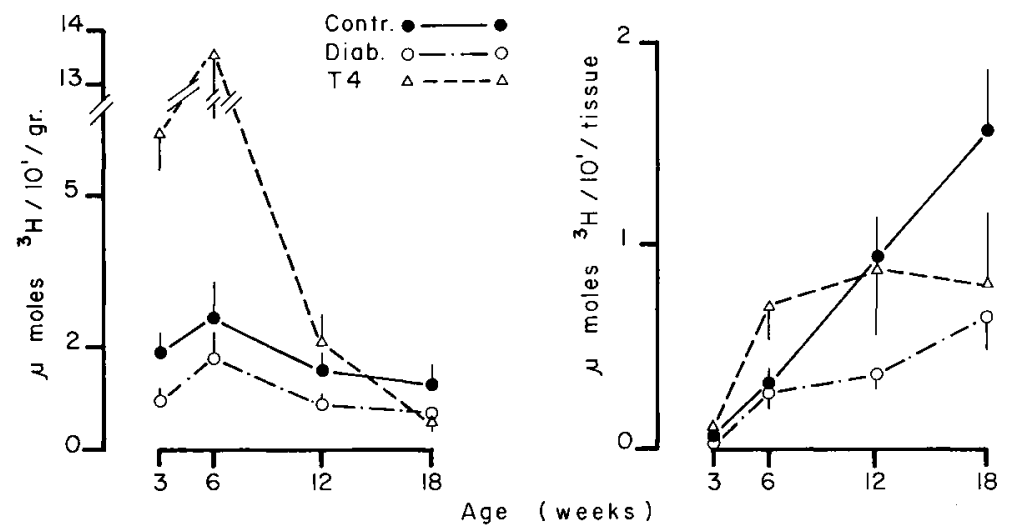

FIG. 1. - Incorporation of ${ }^{3} \mathrm{H}_{2} \mathrm{O}$ in total lipids of the RPAT. The results in control (๑), type-2 diabetic $(\mathrm{O})$ and hyperthyroid $\left(\mathrm{T}_{4}, \triangle 1\right.$ rats are expressed per $g$ of wet weight and per whole tissue. Each value is the mean of 5 to 10 assays. 


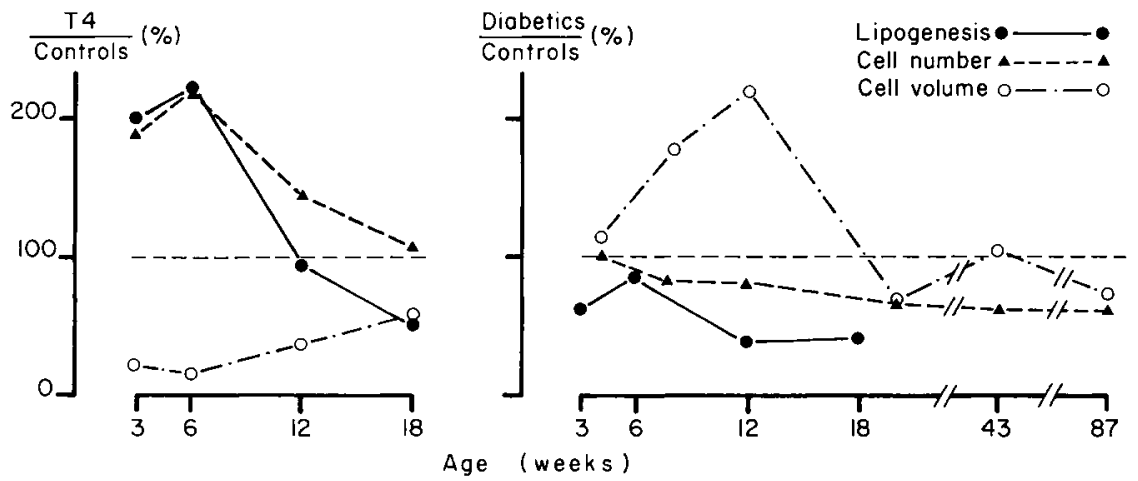

FiG. 2. - RPAT fat cell size and number (obtained from previous experiments) and lipogenesis per fat pad in hyperthyroid $\left(\mathrm{T}_{4}\right)$ and type-2 diabetic rats. The results are expressed as a percentage of the controls.

\section{Discussion.}

The variations in adipose tissue lipogenesis observed in growing control rats agree with the previous results of Gandemer, Pascal and Durand (1982).

Triiodothyronine has been shown to be necessary for the emergence of the lipogenic enzymes implicated in preadipocyte differentiation in culture (GharbiChihi et al., 1981), and this fact could be related to the increment of lipogenesis obtained in young hyperthyroid rats. However, our results are at variance with those reported in hypothyroid rats by Correze et al. (1982) who observed increased lipogenic enzyme activity in young rats. This discrepancy may be due to the fact that our experiments were performed on whole tissue while those in hypothyroid rats were performed on isolated fat cells. Moreover, disorders induced by an excess or a lack of hormones are not necessarily in opposition. The decrease in adipose tissue lipogenesis observed in diabetic rats was in good agreement with the well-established role of insulin on lipid synthesis (see review of Czech, 1977). Moreover, insulin has been shown to enhance fat cell differentiation in cultures of the ob17 cell line (Négrel, Grimaldi and Ailhaud, 1978) or in primary cultures (Björntorp et al., 1980).

No connection could be established between changes in fat cell size and modifications in the lipid synthesis of treated rats compared to the controls; it has been shown that de novo lipogenesis is not correlated to fat cell size in control rats of various ages (Holm et al., 1975 ; Karaoghlanian, 1983). On the contrary, during the growth of the RPAT, we observed a good relationship between relative lipogenesis and relative fat cell number in hyperthyroid or diabetic rats compared to the controls.

In hyperthyroid rats, lipoprotein lipase (LPL) activity per whole fat pad did not change, and LPL expressed per fat cell decreased with cell size (Levacher et al., 1984) ; in 18-week old diabetic rats, there is no modification in LPL activity per whole tissue or per $\mathrm{mg}$ of protein (unpublished data). 
It can be postulated that, while exogenous lipid uptake via LPL is related to variations in fat cell size (Hartman, 1977), changes in de novo lipogenesis are related to the recruitment of new fat cells and to the control of fat cell number. This hypothesis is supported by recent reports showing that adipogenic serum factors dramatically increase the lipogenic enzyme activity in preadipocyte cultures without greatly affecting LPL activity (Ailhaud et al., 1983 ; Löffler et al., 1983).

$10^{e}$ Réunion du groupe Développement I.N.R.A., Rennes, 9-10 mai 1984.

Acknowledgements. - We wish to thank M. F. Kinebanyan for her expert technical assistance and M. F. Bedel for the preparation of the manuscript.

Résumé. Lipogenèse en relation avec le contrôle endocrinien de la cellularité du tissu adipeux chez le rat.

Nous avons suivi, en fontion de l'âge, le taux d'incorporation $d^{\prime 3} \mathrm{H}$ à partir $d^{\prime 3} \mathrm{H}_{2} \mathrm{O}$ dans les lipides totaux du tissu adipeux rétropéritonéal (TARP) de rats diabétiques (type 2), hyperthyroïdiens et témoins. Les rats hyperthyroïdiens, manifestent jusqu'à l'âge de 12 semaines une hyperplasie du TARP et une augmentation de la lipogenèse par $\mathrm{g}$ de poids frais et par pannicule adipeux. Chez les rats diabétiques adultes, on observe une réduction du nombre d'adipocytes et de la lipogenèse par $\mathrm{g}$ de tissu et par pannicule. Nous avons mis en évidence des variations concomitantes du nombre d'adipocytes et de la synthèse lipidique dans le TARP des 2 groupes de rats traités.

\section{Références}

AILHAUD G., AMRI E., CERMOLACCE C., DJIAN P., FOREST C., GAILLARD D., GRIMALDI P., KHOO J., NÉGREL R., SERRERO-DAVE G., VANNIER C., 1983. Hormonal requirement of growth and differentiation of ob17 preadipocyte cells in vitro. Diabete Metab., 9, 125-133.

BJÖRNTORP P., KARLSSON M., PETTERSSON P., SYPNIEWSKA G., 1980. Differentiation and function of rat adipocyte precursor cells in primary culture. J. Lipid Res., 21, 714-723.

CORREZE C., BERRICHE S., TAMAYO L., NUNEZ J., 1982. Effect of thyroid hormones and cyclic AMP on some lipogenic enzymes of the fat cell. Eur. J. Biochem., 122, 387-392.

CZECH M., 1977. Molecular basis of insulin action. Ann. Rev. Biochem., 46, 359.

FAIN J. N., SCOW R. O., URGOITI E. J., CHERNICK S. S., 1965. Effect of insulin on fatty acid synthesis in vivo and in vitro in pancreatectomized rats. Endocrinology, 77, 137-147.

FOLCH J., LEE M., SLOANE-STANLEY G. H., 1957. A simple method for the isolation and purification of total lipids from animal tissue. J. biol. Chem., 226, 487-509.

GANDEMER G., PASCAL G., DURAND G., 1982. In vivo changes in the rates of total lipid and fatty acid synthesis in liver and white adipose tissues of male rats during postweaning growth. Int. J. Biochem., 14, 797-804.

GHARBI-CHIHI J., GRIMALDI P., TORRESANI J., AILHAUD G., 1981. Triiodothyronine and adipose conversion of ob17 preadipocytes : binding to high affinity sites and effects on fatty acid synthesizing and esterifying enzymes. J. Recept. Res., 2, 153-173.

GOURSOT R., PORTHA B., LEVACHER C., PICON L., 1981. Effect of early and chronic hypoinsulinism on adipose tissue cellularity in the rat. Diabetologia, 21, 418-421. 
HARTMAN A. D., 1977. Lipoprotein lipase distribution in rat adipose tissues : effect on chylomicron uptake. Am. J. Physiol., 232, E316-E323.

HOLM G., JACOBSSON B., BJÖRNTORP P., SMITH U., 1975. Effects of age and cell size on rat adipose tissue metabolism. J. Lipid Res., 16, 461-464.

KARAOGHLANIAN Z., 1983. Personal communication.

LEVACHER C., SZTALRYD C., KINEBANYAN M. F., PICON L., 1984. Effects of thyroid hormones on adipose tissue development in Sherman and Zucker rats. Am. J. Physiol., 246, C50-C56.

LÖFFLER G., FEICK P., HAUNER H., HERBERG L., 1983. An adipogenic serum factor in genetically obese rodents. FEBS Lett., 153, 179-182.

NÉGREL R., GRIMALDI P., AILHAUD G., 1978. Establishment of preadipocyte clonal line from epididymal fat pad of ob/ob mouse that responds to insulin and to lipolytic hormones. Proc. nat. Acad. Sci. USA, 75, 6054.

PORTHA B., PICON L., ROSSELIN G., 1979. Chemical diabetes in the rat as the spontaneous evolution of neonatal diabetes. Diabetologia, 17, 371-377. 